A. Gillespie and W.C.G. Burns (eds.) Climate change in the South Pacific: Impacts and Responses in Australia, New Zealand and Small Island States, 289-301. CKlewer Academic Publishers, The Netherlands.

\title{
HOW SOUTH PACIFIC MANGROVES MAY RESPOND TO PREDICTED CLIMATE CHANGE AND SEA-LEVEL RISE
}

\author{
Joanna C. Ellison \\ School of Applied Science, University of Tasmania, P. O. Box 1214, \\ Launceston, Tasmania 7250, Australia.
}

\begin{abstract}
In the Pacific islands the total mangrove area is about 343,735 ha, with largest areas in Papua New Guinea, Solomon Islands, Fiji and New Caledonia. A total of 34 species of mangroves occur, as well as 3 hybrids. These are of the Indo-Malayan assemblage (with one exception), and decline in diversity from west to east across the Pacific, reaching a limit at American Samoa. Mangrove resources are traditionally exploited in the Pacific islands, for construction and fuel wood, herbal medicines, and the gathering of crabs and fish.
\end{abstract}

There are two main environmental settings for mangroves in the Pacific, deltaic and estuarine mangroves of high islands, and embayment, lagoon and reef flat mangroves of low islands. It is indicated from past analogues that their close relationship with sea-level height renders these mangrove swamps particularly vulnerable to disruption by sea-level rise. Stratigraphic records of Pacific island mangrove ecosystems during sea-level changes of the Holocene Period demonstrate that low islands mangroves can keep up 
with a sea-level rise of up to $12 \mathrm{~cm}$ per 100 years. Mangroves of high islands can keep up with rates of sea-level rates of up to $45 \mathrm{~cm}$ per 100 years, according to the supply of fluvial sediment. When the rate of sealevel rise exceeds the rate of accretion, mangroves experience problems of substrate erosion, inundation stress and increased salinity.

Rise in temperature and the direct effects of increased $\mathrm{CO}_{2}$ levels are likely to increase mangrove productivity, change phenological patterns (such as the timing of flowering and fruiting), and expand the ranges of mangroves into higher latitudes.

Pacific island mangroves are expected to demonstrate a sensitive response to the predicted rise in sea-level. A regional monitoring system is needed to provide data on ecosystem changes in productivity, species composition and sedimentation. This has been the intention of a number of programs, but none has yet been implemented.

\section{Mangroves of the South Pacific Islands}

\section{A. Mangrove Areas and Distributions}

Mangrove forests occur on low energy, sedimentary shorelines of the tropics, generally between mean tide and high tide elevations. Mangrove trees have special physiological and morphological adaptations to the environmental stresses of their intertidal habitat, of high salinity, low oxygen, poor nutrient availability and substrate mobility. Mangrove ecosystems are characterized by high faunal diversity of microbes (bacteria, Protozoa, fungi), invertebrate infauna (i.e. crabs), fish and birds.

In the Pacific islands the total area of mangroves is about 343,735 ha, the largest areas occurring in Papua New Guinea, Solomon Islands, Fiji and New Caledonia (Table 1). The world mangrove area is estimated at 14,197,635 ha (Lacerda et al., 1993); hence, the Pacific islands have $2.42 \%$ of the worlds mangroves. The mangrove area of the Pacific islands is small in global terms, but each island group has a unique community structure, and the mangrove forests provide significant uses for human populations. 
The greatest diversity of mangroves in the world is southern Papua New Guinea owing to its location at the centre of the Indo-Malayan mangrove center of diversity, with 33 species and 2 hybrids (Ellison, 1995). Mangrove species diversity declines from Papua New Guinea east across the Pacific Islands (Figure 1; Ellison, 1995), and the eastern limit of mangroves is American Samoa. Mangroves do not occur further east due to difficulty of long-distance dispersal of propagules, and loss of habitats due to sea-level changes of the past (Ellison 1991; Ellison 1994a). Mangroves have been introduced in Hawaii and French Polynesia.

\section{B. Uses of Mangrove Forests}

Mangrove resources have been traditionally exploited in the Pacific islands, for construction and fuel wood, herbal medicines, and the gathering of crabs and fish. In the last few centuries of economic development significant areas have been lost to reclamation for settlement or agriculture, and others have been degraded by the dumping of rubbish. This continues today; for example, all significant mangrove areas in Tonga are now allocated for clearance (Plate 1). Despite the traditional use of mangroves in the Pacific islands, they are rarely a valued resource.

Legislation for the protection of mangroves exists in many Pacific island nations, but enforcement of such laws is usually lax. More mangrove protected areas need to be established to ensure that sufficient mangrove ecosystem biomass remains in each island nation for use by future generations. Mangrove conservation values can be enhanced by development of educational resource materials, for distribution in schools and community fora.

Research needs to be carried out on forest community structure, primary productivity, ecology, foodchains, fish, crustaceans, and other fauna. This would facilitate evaluation of the use of mangrove production by groups of organisms in adjacent systems, and bolster justification for mangrove protection. It would also provide guidelines for sustainable exploitation of the mangrove forest. 


\section{Impact of Climate Change on Mangrove Ecosystems}

Concern over the capacity of intertidal wetlands to respond to climatic and sea-level change has developed as a result of investigations of palaeo records (reviewed by Woodroffe 1990; Ellison and Stoddart 1991; Parkinson et al. 1994 and Bacon 1994) and mangrove ecophysiological response to climatic change (reviewed by Pernetta 1993; Seminiuk 1994; Ellison 1994b and Snedaker 1995). These studies show that intertidal wetlands are likely to be one of the most sensitive ecosystems vis-à-vis predicted climate change due to their sensitivity to temperature (Saenger \& Moverley 1985, Duke 1990), salinity (Ball 1988), ambient $\mathrm{CO}_{2}$ (Farnsworth et al., 1996), and in particular because of the close relationship between the health of intertidal vegetation communties and sea-level (Woodroffe 1990; Ellison and Stoddart 1991).

The consequences of climate change on mangrove ecosystems are assessed below, identifying the processes that will respond to climate change, the direction of community response, the maximum rates of change that can be withstood, and implications for management and planning in mangrove areas.

\section{A. Mangroves and Sea-Level Rise}

Large mangrove ecosystems develop on sedimentary shorelines of gentle gradient, between mean sea level (MSL) and the level of mean high water spring tides. Growing in the upper half of the tidal range, their close relationship with sea-level position renders mangrove swamps particularly vulnerable to disruption by sea-level rise. With most Pacific islands having a tidal range of less than $1 \mathrm{~m}$, mangrove ecosystems will be disrupted by a sea-level rise of $0.3 \mathrm{~m}$, and will retreat landwards with a sea-level rise of 1 $\mathrm{m}$. However, as discussed later in this chapter, factors such as physiographic location, tidal range, species assemblage and sediment supply contribute to heterogeneity in mangrove response to rising sealevel, investigated below. 
Research to investigate sea-level rise impacts on mangroves falls into two areas. First, sea-level effects on an ecosystem can be reconstructed from the past, by analysis of stratigraphic deposits, provided the evidence is available from micro-fossils (i.e. pollen, diatoms) that can be used to indicate the vegetation and environmental conditions. This technique has the advantage of indicating long-term complex system response, though detail of short-term individual responses of species is usually only speculative. Second, present day case studies can be examined, such as areas of the world where sea-level rise is occurring, or areas where flooding of mangroves has been carried out for mosquito control. From these approaches, monitoring programmes can be developed for identification of changes in the mangrove ecosystem resulting from climate change and sea-level rise.

\section{Past records of mangrove response to sea-level rise}

Within the intertidal habitat of mangroves, species have different preferences for elevation, salinity and frequency of inundation, resulting in species zones. Elevation of the ground surface can be raised under mangroves, by accumulation of vegetative detritus to form a mangrove peat or mud, which may also contain matter brought in by the tides and by rivers. If the sedimentation rate keeps pace with rising sea-level, then the salinity and frequency of inundation preferences of mangrove species zones will remain largely unaffected. If the rate of sea-level rise exceeds the rate of sedimentation, then mangrove species zones will migrate inland to their preferred elevation, and seaward margins will die back. The accumulation of sediment under mangroves will help to compensate for rising sea-levels. However, expected rates of sedimentation must be established to assess the vulnerability of mangrove ecosystems. This requires analysis of Holocene stratigraphy.

Stratigraphy of Pacific island mangroves indicates that mangroves became established in expansive swamps during the middle of the Holocene Period, about 6500 years ago (Ellison and Stoddart, 1991). Before this time they were limited by the interactive factors of rapid sea-level rise and the absence of sedimentary shorelines. Mangroves probably survived this 
period as individual trees, as seen today on shorelines with too steep of a gradient or that are too exposed for expansive swamp development.

There are two major environmental settings for mangroves of the Pacific, deltaic and estuarine mangroves of high islands, and embayment, lagoon and reef flat mangroves of low islands. Deltaic and estuarine mangroves occur on islands sufficiently high to develop a river system, and so deliver significant quantities of sediment to the coastal zone. These areas contain the most extensive mangroves af the Pacific islands, for example the Fly delta in PNG, the Rewa delta in Viti Levu, the Dumbéa delta in New Caledonia, and the estuaries of Palau and Pohnpei. The mangrove areas receive fluvial sediment from the catchment, and also accumulate vegetative debris to form a mud. Stratigraphic reconstruction reveals fairly rapid accretion of up to $45 \mathrm{~cm}$ per 100 years (Ellison and Stoddart, 1991).

Embayment, harbour and lagoon mangroves of low islands can be extensive where fine sediment accumulates to form a broad intertidal slope. Low island mangroves do not have an external supply of sediment, and build up their substrate by accumulation of vegetative detritus to form a highly organic peat. Mangrove stratigraphy from low island mangrove ecosystems indicates rates of accumulation of up to $12 \mathrm{~cm}$ per 100 years (Ellison, 1989; Ellison, 1993). This reflects the rate of peat production within the mangrove system, there being few sources of inorganic sediment in these environments.

Comparison of mangrove stratigraphy shows that low island mangroves are more susceptible to disruption by rising sea-level owing to relatively low rates of sediment accretion. Stratigraphy from high islands and continental coastlines, that have more sediment coming off the land into intertidal areas from rivers and longshore drift, indicates that mangrove ecosystems in these areas will be better able to keep pace with sea-level rise. Low island mangroves could keep up with sea-level rise of up to $12 \mathrm{~cm}$ per 100 years. High island mangroves could keep up with rates of $45 \mathrm{~cm}$ per 100 years, provided the sediment supply is not restricted by construction, such as dams on rivers leading to mangrove deltas.

While the consequences of greenhouse-induced climate change are probably not as dramatic as feared in the late 1980's, sea-level rise 
remains an issue for coastal ecosystems such as mangroves. The magnitude of sea-level rise that can be anticipated is based upon the findings of the WMO /UNEP Inter Governmental Panel on Climate Change (Houghton et al, 1996). In summary, in the last 100 years there has been a rise of $10-25 \mathrm{~cm}$ in global eustatic sea-level and the IPCC working group predicted a future sea-level rise of $15-95 \mathrm{~cm}$ by 2100 , (mid range $50 \mathrm{~cm}$ ). This would imply mean rates of rise of between $5 \mathrm{~cm}$ per decade over the next century. Comparison with the rates of mangrove accretion indicates that island mangroves will experience serious problems with rising sealevel in the next 50 years, and low island mangroves could already be under stress. Examples of low islands in the Pacific with mangrove areas include Tongatapu (Tonga), the Marshall Islands, Kiribati and Tuvalu.

\section{Present Case Studies}

The reasons for the inability of mangroves to keep up with higher rates of sea-level rise is not apparent from past reconstructions of events. Some problems are demonstrated by mangrove dieback in Bermuda, a low island with a long tide gauge record of relatively rapid sea-level rise (Ellison, 1993). There are also other studies which indicate the problems which may develop in mangroves during rapid sea-level rise.

\section{EROSION}

Bermuda is a low limestone island without rivers, and the most northerly location for mangroves. Tide gauge records since 1932 show sea-level rise at a rate of $28 \pm 18 \mathrm{~cm}$ per 100 years (Pirazzoli, 1986). The largest mangrove area $(6.26$ acres $)$ at Hungry Bay has for the last 2000 years been building peat at a rate of 8.5 to $10.6 \mathrm{~cm}$ per 100 years (Ellison, 1993). The rate of sea-level rise has exceeded the rate of sediment accretion, leading to retreat of the seaward margin and erosion. The substrate elevation of the seaward margin of mangroves is below mean sea-level, the normal lower limit for mangroves. Retreat of the seaward edge has caused loss of 2.24 acres of mangroves, commencing in the last few hundred years, with a second dieback between 1900 and 1947, and a third dieback in the last decade. Stratigraphy shows that before 4000 years ago sealevel rose at a rate of $25 \mathrm{~cm}$ per 100 years, from 4000 to 1000 years ago 
the rate of sea-level rise declined to $6 \mathrm{~cm}$ per 100 years during which time mangroves were established, and in the last 1000 years there was an increase to $14.3 \mathrm{~cm}$ per 100 years, during which time the mangroves died back.

The record from Bermuda demonstrates that mangrove sediment is subject to erosion by rising sea-levels, with removal of mangrove substrate (above MSL) and with some deposition subtidally offshore of the mangroves (Ellison, 1993). This corresponds with the Bruun Rule, which has shown erosion of beach sediment to occur with sea-level rise (Bruun, 1962; Schwartz, 1967). Sheet erosion occurs at the peat surface, indicated by a 20 to $25 \mathrm{~cm}$ difference between the peat level above a small cliff and the former peat surface as indicated by exposed horizontal roots of Avicennia. As trees recede and loosen the sediment, more rapid erosion occurs and forms a 40-50 cm small cliff. Such erosion exacerbates the existing problem, for as the mangrove substrate surface is lowered and creeks widen, the differential between elevation and MSL increases.

Similar erosion patterns, with reversed succession as elevation declines, have been described by Semeniuk (1980) in N.W. Australia. The effect of sheet erosion on mangrove zonation is migration of pioneer/ seaward mangroves into more landward zones. The effect of cliffing on mangrove zonation is loss of the seaward zone, leading to truncated zonation and narrow fringes. The effect of tidal creek erosion is slumping of banks and loss of trees.

Erosion of mangrove substrate would seem to be a major problem in cases of sea level rise. It is indicated that the Bruun Rule of beach erosion with sea-level rise is also apposite for mangrove swamps, and may occur earlier owing to the finer texture of the sediment.

\section{INCREASED SALINITY}

Increase in salinity in mangroves leading to salt stress can result from a number of factors in addition to sea-level rise, such as groundwater depletion owing to reduced freshwater flux, groundwater extraction, and reduced rainfall. Two major physiological adaptations enable mangrove 
survival in saline ocean water (Scholander, et al., 1962), salt exclusion in species of Rhizophora and Laguncularia, and salt excretion in species of Aegialitis and Aegiceras. Salt excluders also cease or diminish transpiration and photosynthesis when exposed to saline water. Salt secretors can continue photosynthesis utilizing ocean water in transpiration, owing to salt glands in the leaves.

Stern and Voight (1959) grew 200 seedlings of Rhizophora mangle under different salinities, finding that seedling survival and growth increase by dry weight and seedling height were all inversely related to salt concentrations of the growing solutions. Ball and Farquhar (1984a) studied gas exchange characteristics in Aegiceras corniculatum and Avicennia marina under different salinity and humidity conditions. They showed decreased photosynthetic capacity with increase of salinity, with Aegiceras being the more sensitive. Ball and Farquhar, 1984b) studied the gas exchange characteristics of Avicennia marina with increasing salinity, finding that $\mathrm{CO}_{2}$ assimilation rate, stomatal conductance, intercellular $\mathrm{CO}_{2}$ concentration and evaporation rate all decreased. Increased salinity has the effect of decreasing net primary productivity and results in reduced growth, with a differential effect on species. Reduced precipitation and a rise in sea-levels could result in stress to and changing competition between mangrove species.

The shallow water table of S. Florida is susceptible to saline intrusion from sea-level rise and groundwater extraction owing to low topography and porous rock. Alexander (1974) and Alexander and Crook (1974) found evidence of pine stumps in salt water mangrove areas of Key Largo and landward encroachment of mangroves into grasslands and cypress swamps. Sternberg and Swart (1987) used stable isotopes in plant stem water to determine relative ocean water and fresh water utilization in plants. They concluded that mangroves can utilize water ranging from fresh to oceanic, indicating plasticity in the salt-tolerant physiological system. Thus, we can infer that mangroves gain a competitive edge over faster growing glycophylic plants in conditions of increasing salinity.

In the Northern Territory of Australia, Woodroffe and Mulrennan (1993) have documented dramatic recent changes to the Lower Mary River floodplain, with saltwater intrusion and upstream expansion of the tidal 
creek network. This has resulted in the death of freshwater wetland communities with loss of $60 \mathrm{~km}^{2}$ of Melaleuca forest and upstream invasion of mangroves. There are a number of possible reasons for these events, including relative sea-level rise (Woodroffe, 1995). Similar, though less spectacular, extension of creeks has occurred on other river systems, such as the Alligator rivers (Woodroffe, 1995). Loss of freshwater wetlands with saline intrusion is documented in the Florida Keys (Ross, et al., 1994), where longer tide records have enabled researchers to attribute the cause to relative sea-level rise.

\section{INUNDATION}

Impoundment of mangroves for mosquito control provides an analogy to the effects of increased inundation with sea-level rise. Harrington and Harrington (1982) recorded extensive death of Avicennia germinans and Rhizophora mangle at India River, East Florida following 4 months of 30-45 $\mathrm{cm}$ depth of flooding of an impoundment. Inundation was suddenly onset, then sustained over the period. The natural tidal range in this area is $10-20$ cm (Lahmann, 1988).

Naidoo (1983) found that prolonged flooding resulted in lower ability of leaves to conduct water; an increase in stomatal closing; and, degeneration of chloroplasts in Bruguiera gymnorrhiza, leading to reduced rates of photosynthesis. When lenticels of aerial roots become inundated, oxygen concentrations in the plant fall dramatically (Scholander, 1955). If inundation is sustained, low oxygen conditions occur and mortalities follow. This is thought to have been the cause of widespread mortality of Avicennia germinans stands in Puerto Rico recorded by Jimenez et al. (1985), following permanent flooding caused by adjacent dredging.

Lahmann (1988) found that rates of litterfall in an impounded mangrove forest in Florida were reduced relative to natural fringe forest during flooded months. This indicates that the above ground net productivity of Rhizophora mangle is reduced by flooding, though phenology (such as the timing of flowering and fruiting) was not changed. Over several years of flooding survival of Avicennia germinans and Laguncularia racemosa seedlings was prevented, and Rhizophora mangle became more common, 
despite poor seedling establishment during flooded periods. The depth of flooding was not indicated in this study.

\section{B. Other Impacts of Climate Change on Mangroves}

\section{Climate warming}

Climate warming should have a beneficial effect on mangrove ecosystems, with increased productivity and expansion of ranges of species.

Mangrove forest ecosystems border herbaceous salt marsh ecosystems in subtropical latitudes, at the $16^{\circ} \mathrm{C}$ isotherm for air temperature of the coldest month, at the margins of incidence of ground frost, and where water temperatures never exceed $24^{\circ} \mathrm{C}$. At these limits species of $\underline{\text { Avicennia }}$ occur, Avicennia marina (grey mangrove) reaching the highest latitude in the South Pacific at Victoria in S.E. Australia $\left(38^{\circ} \mathrm{S}\right)$ and $37^{\circ} \mathrm{S}$ in North Island, New Zealand.

With climate warming these higher latitude marginal mangroves can be expected to increase in diversity, with expansion of the ranges of other mangrove species into mangrove margins only occupied currently by Avicennia species, and expansion of the ranges of mangroves into salt marsh environments. The heterogeneity of regional sea surface temperature limits of mangrove species ranges would indicate regional differences in mangrove response. Variable gradients of sea surface isotherms mean that, for example, the expansion of range in the southeastern United States will be limited relative to that in southeastern Australia or southeastern Africa.

Combined with higher atmospheric $\mathrm{CO}_{2}$ levels (discussed below), climate warming can be expected to increase mangrove productivity, characterized by increased growth and litter production at all locations.

\section{Increased $\mathrm{CO}_{2}$}


As well as its climate effects, increased $\mathrm{CO}_{2}$ directly affects plant growth and development. Plants have different pathways of carbon fixation in photosynthesis, and mangroves operate the $\mathrm{C}_{3}$ pathway (Clough et al. 1982). In this case, metabolic responses with increased atmospheric $\mathrm{CO}_{2}$ are increased productivity and more efficient water use (Warrick et al. 1987). Farnsworth et al. (1996) grew seedlings of Rhizophora mangle in doubled levels of $\mathrm{CO}_{2}$ and demonstrated significantly increased biomass, total stem length, branching activity and total leaf area compared with seedlings grown in normal levels of $\mathrm{CO}_{2}$. Increase in atmospheric $\mathrm{CO}_{2}$ can be expected to improve mangrove tree growth and litter production.

\section{Precipitation changes}

Most the world's mangroves are found in warm humid regions, with much more limited areas on drier coastlines. In equatorial and tropical summer rainfall regions mangroves are tall, dense and floristically diverse. In subtropical dry regions mangroves are low, scattered and sporadic. Mangrove diversity is a function of rainfall patterns, with the greatest abundance of species in areas of higher rainfall, owing to the benefits from fluvial runoff of sedimentation and nutrient supply.

The reasons for these patterns relate to salt stress. Under humid conditions, mangrove soils are almost continuously leached by heavy rains and fresh water is available from river discharge and groundwater outflow, which provides nutrients. Under arid conditions, evaporation from the intertidal mangroves at low tide leads to high concentrations of salt, in some cases resulting in unvegetated hypersaline flats around high tide level.

The IPCC found evidence of increase in precipitation over the equatorial Pacific in the last few decades, with decreases to the north and south (Houghton et al., 1996: 25). Scenarios of future climate change all show an enhanced global mean hydrological cycle, but with uncertainties as to how this will affect rainfall patterns in the Pacific island area.

Snedaker (1995) has postulated that changes in rainfall patterns will have a significant effect on mangrove ecosystems. Increased rainfall should 
result in reduced salinity and exposure to sulphate, and an increase in delivery of terrigenous nutrients. Mangrove park managers can expect decreased rainfall and increased evaporation to reduce the extent of mangrove areas, particularly with loss of the landward zone to unvegetated hypersaline flats. The number of mangrove zones and their diversity can be expected to decrease, and growth rates will also likely decline. In conditions of increased rainfall the extent of mangrove areas can be expected to increase, with colonization of previously unvegetated areas of the landward fringe, and the diversity of mangrove zones and growth rates should increase.

These responses of Pacific island mangroves to changes in precipitation will occur in combination with response to climate warming, increased $\mathrm{CO}_{2}$ and sea-level rise. The net response of mangroves at each location will also be combined with local factors and other impacts. Understanding and management of these changes will require data the nature of mangrove changes in the region.

\section{Monitoring of Climate Change Effects}

Mangrove tidal wetlands are expected to show a sensitive response to predicted climate change and sea-level rise (Woodroffe 1990; Ellison and Stoddart, 1991). The nature of this response is complex, and subject to factors related to environmental setting (Semeniuk 1994, Bacon 1994), such as location on low or high islands. Sea-level position is central to the functional ecology of a mangrove swamp, and rise in sea-level will perturb every aspect of the ecosystem. This combined with effects of climate change, and stresses from storms and human disturbances will cause mangroves to experience disruption and area losses in the next few decades.

Certain identification of climate change and sea-level rise effects on mangroves requires long term monitoring of biological and physical parameters at a network of locations using standard techniques. This would allow comparison of data in order to distinguish a regional trend in change from that resultant from local effects. Though aimed at distinguishing climate change effects, the monitoring system would therefore also show local effects and disturbances, which would provide environmental 
managers with ecological data to allow for informed management of mangrove ecosystems.

Several expert groups have identified the need for a global monitoring system of mangrove response to climate change (UNEP-IOC-WMO-IUCN, 1991; UNEP 1994), but none to date has been implemented. Implementation of such a system may finally come to fruition with the UNEP-IOC-WMO-IUCN Long-Term Global Monitoring System of Coastal and Near Shore Phenomena Related to Climate Change (UNEP-IOCWMO-IUCN, 1991), which is to be established as part of the Global Ocean Observing System. In the South Pacific region, SPREP recently developed a Regional Wetland Action Plan, in which actions 3.3.1 and 3.3.5 call for development of a regional monitoring system for mangrove ecosystem health (Idechong et al., 1995). Such a regional monitoring networks would assist informed management with respect to climate change effects on mangroves.

\section{Acknowledgement}

This contribution was written under an Australian Postdoctoral Research Fellowship for research into sea-level rise effects on mangroves.

\section{References}

Alexander, T.R. and Crook, A.G., 1974. Recent vegetational changes in southern Florida. In P. J. Gleason (Editor)., Environments of South Florida: Present and Past. Miami Geological Society Memoir 2, Miami, pp. 61-72.

Alexander, T.R., 1974. Evidence of recent sea-level rise derived from ecological studies on Key Largo, Florida. In: P.J. Gleason (Editor)., Environments of South Florida: Present and Past. Miami Geological Society Memoir 2, Miami, pp. 219-222.

Bacon, P. R., 1994. Template for evaluation of impacts of sea-level rise on Caribbean coastal wetlands. Ecological Engineering 3, 171-186. 
Ball, M.C. and Farquhar, G.D., 1984a. Photosynthetic and stomatal responses of two mangrove species, Aegiceras corniculatum and Avicennia marina, to long term salinity and humidity conditions. Plant Physiology, 74: $1-6$.

Ball, M.C. and Farquhar, G.D., 1984b. Photosynthetic and stomatal responses of grey mangrove, Avicennia marina, to transient salinity conditions. Plant Physiology ${ }_{2}$ 74: 7-11.

Ball, M. C. 1988. Salinity tolerance in mangroves Aegiceras corniculatum, and Avicennia marina I. Water use in relation to growth, carbon partitioning, and salt balance. Australian J. Plan. 15, 447-464.

Bruun, P., 1962. Sea level rise as a cause of shore erosion. Journal of the Waterways and Harbours Division, Proceedings of the American Society of Civil Engineers, 88: 117-130.

Clough, B.F., Andrews, T.J. \& Cowan, I.R. 1982. Physiological processes in mangroves. In: Clough, B. F., (ed.), Mangrove ecosystems in Australia. Australian Institute of Marine Science \& Australian National University, Canberra,. 193-210.

Duke N.C. 1990. Phenological Trends with Latitude in the Mangrove Tree Avicennia marina. Journal of Ecology, 78: 113-133.

Ellison, J.C., 1989. Pollen analysis of mangrove sediments as a sea level indicator: Assessment from Tongatapu, Tonga. Palaeogeography, Palaeoclimatology, Palaeoecology, 74: 327-341.

Ellison, J.C., 1991. The Pacific palaeogeography of Rhizophora mangle L. (Rhizophoraceae). Botanical Journal of the Linnean Society 105: 271-284.

Ellison, J.C., 1993. Mangrove retreat with rising sea-level, Bermuda. Estuarine Coastal and Shelf Science 37: 75-87.

Ellison, J. C., 1994a. Palaeo-lake and swamp stratigraphic records of Holocene vegetational and sea-level changes, Mangaia, Cook Islands. Pacific Science, 48, 1-15. 
Ellison, J. C., 1994. Climate change and sea-level rise impacts on mangrove ecosystems. In J. Pernetta, R. Leemans, D. Elder, \& S. Humphreys, Eds., Impacts of Climate Change on Ecosystems and Species: Marine and Coastal Ecosystems. IUCN, Gland, pp. 11-30.

Ellison, J.C., 1995. Systematics and distributions of Pacific Island mangroves. In Marine and Coastal Biodiversity in the Tropical Island Pacific Region: Volume I. Species Systematics and Information Management

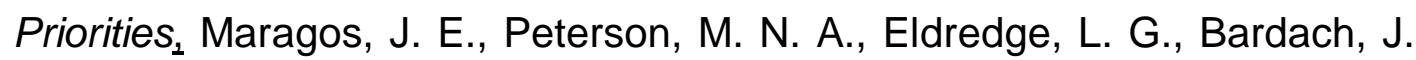
E. and Takeuchi, H. F. Eds., East West Center, Honolulu, 59-74.

Ellison, J. C. and D. R. Stoddart, 1991. Mangrove ecosystem collapse during predicted sea-level rise: Holocene analogues and implications. Journal of Coastal Research 7, 151-165.

Farnsworth, E. J., Ellison, A. M. and Gong, W. K., 1996. Elevated $\mathrm{CO}_{2}$ alters anatomy, physiology, growth and reproduction of red mangrove (Rhizophora mangle L.). Oecologia 108: 599-609.

Harrington, R.W. and Harrington, E.S., 1982. Effects on fishes and their forage organisms of impounding a Florida salt marsh to prevent breeding by salt marsh mosquitos. Bulletin of Marine Science 32: 523-531.

Houghton, J. T., Meira Filho, L. G., Callander, B. A., Harris, N., Kattenberg, A. and Maskell, K. Eds. (1996). Climate Change 1996. The Science of Climate Change. Cambridge University Press, Cambridge, 572pp.

Idechong, N., Ellison, J. \& Jaensch, R. (1995). A Draft Regional Wetlands Action Plan for the Pacific Islands. Pp.116-134 in International Coral Reef Initiative Pacific Regional Workshop Report (Suva, Fiji, 27 Nov-1 Dec 1995). South Pacific Regional Environment Programme, Apia.

Jimenez, J.A., Martinez, R. and Encarnacion, L., 1985. Massive tree mortality in a Puerto Rican mangrove forest. Caribbean Journal of Science, 21: 75-78. 
Lacerda, L.D., Conde, J.E., Alarcon, C., Alvarez-Leon, R., Bacon, P.R., D'Croz, L., Kjerfve, B., Polaina, J. and Vannucci, M., 1993. Mangrove ecosystems of Latin America and the Caribbean: a summary. In Conservation and Sustainable Utilization of Mangrove Forests in Latin America and Africa Regions, Ed. L. D. Lacerda, 1-42. Okinawa: International Tropical Timber Organization and International Society for Mangrove Ecosystems.

Lahmann, E.J., 1988. Effects of different hydrological regimes on the productivity of Rhizophora mangle L. A case study of mosquito control impoundments at Hutchinson Island, Saint Lucie County, Florida. Ph.D. dissertation, University of Miami, $149 \mathrm{pp}$.

Naidoo, G., 1983. Effects of flooding on leaf water potential and stomatal resistance in Bruguiera gymnorrhiza. New Phytologist, 93: 369-373.

Parkinson, R. W., DeLaune, R. D. and White, J. R., 1994. Holocene sealevel rise and the fate of mangrove forests within the wider Caribbean region. Journal of Coastal Research , 10, 1077-1086.

Pernetta, J. C., 1993. Mangrove forests, climate change and sea-level rise. IUCN, Gland, 46pp.

Pirazzoli, P. A. 1986. Secular trends of relative sea-level (RSL) changes indicated by tide-gauge records. Journal of Coastal Research 1, 1-126.

Ross, M.S., O Brien J.J. and Sternberg, L.D., 1994. Sea level rise and the reduction of pine forests in the Florida keys. Ecological Applications, 4, 144.

Saenger P. and Moverley J. 1995 Vegetative phenology of mangroves along the Queensland coastline. Proc. Ecol. Soc. Aust. 13 257-265.

Scholander, P.F., Hammel, H.T., Hemmingsen, E. and Garey, W., 1962. Salt balance in mangroves. Plant Physiology, 37: 722-729.

Scholander, P.F.L., Van Dam, L., and Scholander, S.I., 1955. Gas exchange in roots of mangroves. American Journal of Botany, 42: 92-98. 
Schwartz, M.L., 1967. The Bruun theory of sea level rise as a cause of shore erosion. Journal of Geology, 75: 76-92.

Scott, D. A. 1993. A Directory of Wetlands in Oceania. Slimbridge: International Waterfowl and Wetlands Research Bureau and Kuala Lumpar: Asian Wetland Bureau.

Semeniuk, V., 1980. Mangrove zonation along an eroding coastline in King Sound, North-Western Australia. Journal of Ecology, 68: 789-812.

Semeniuk, V., 1994. Predicting the effect of sea-level rise on mangrove in northwestern Australia. Journal of Coastal Research, 10, 1050-1076.

Snedaker, S. C., 1995. Mangroves and climate change in the Florida and Caribbean region: scenarios and hypotheses. Hydrobiologia, 295, 43-49.

Stern, W.L. and Voight, G.K., 1959. Effect of salt concentration on growth of red mangrove in culture. Botanical Gazette, 131: 36-39.

Sternberg, L. da S.L. and Swart, P.K., 1987. Utilization of freshwater and ocean water by coastal plants of southern Florida. Ecology, 68: 1898-1905.

UNEP-IOC-WMO-IUCN, 1990. UNEP-IOC-WMO-IUCN Meeting of Experts on a Long-Term Global Monitoring System of Coastal and Near Shore Phenomena Related to Climate Change. Intergovernmental Oceanographic Commission Report of Meetings of Experts and Equivalent Bodies 61.

UNEP-IOC-WMO-IUCN, 1991. Meeting of Experts on a Long-Term Global Monitoring System of Coastal and Nearshore phenomena, Pilot projects on mangroves and coral reefs. Intergovernmental Ocenaographic Commission Report of Meetings of Experts and Equivalent Bodies 69.

UNEP, 1994. Assessment and Monitoring of Climatic Change Impacts on Mangrove Ecosystems. UNEP Regional Seas Reports and Studies No 154.

UNEP/ UNESCO 1993. Impact of expected climate change on mangroves. UNESCO Report in Marine Science 61. 
Woodroffe, C.D., 1981. Mangrove swamp stratigraphy and Holocene transgression, Grand Cayman Island, West Indies. Marine Geology, 41: 271-294.

Woodroffe, C. D. 1990. The impact of sea-level rise on mangrove shorelines. Progress in Physical Geography 14, 483-520.

Woodroffe, C. D., 1995. Response of tide dominated mangrove shorelines in Northern Australia to anticipated sea-level rise. Earth Surface Processes and Landforms, 20, 65-85.

Woodroffe, C. D. and Mulrennan, M. E., 1993. Geomorphology of the Lower Mary River Plains, Northern Territory. North Australia Research Unit, Darwin, 152pp. 
Table 1. Mangrove areas and species diversity in the Pacific islands (from Ellison, 1995).

\begin{tabular}{lll}
\hline Island Group & $\begin{array}{l}\text { Mangrove }^{1} \\
\text { species }\end{array}$ & $\begin{array}{l}\text { Mangrove } \\
\text { Area (ha) }\end{array}$ \\
\hline Papua New Guinea & $33(2)$ & 200,000 \\
Palau & 13 & 4,708 \\
Northern Mariana Islands & 5 & \\
Guam & 11 & 70 \\
Federated States of Micronesia & 14 & 8,564 \\
Marshall Islands & 5 & \\
Nauru & 2 & 1 \\
Solomon Islands & $20(2)$ & 64,200 \\
Vanuatu & 14 & $2,750 ?$ \\
New Caledonia & $14(2)$ & 20,250 \\
Kiribati & 4 & \\
Tuvalu & 2 & 40 \\
Fiji & $8(1)$ & 41,000 \\
Tonga & 8 & 1,000 \\
Western Samoa & 3 & 700 \\
American Samoa & 3 & 52 \\
Niue & 1 & \\
French Polynesia & 1 & (introduced) \\
Hawaii & 2 & (introduced) \\
TOTAL & & \\
& 34 (3) & 343,735 \\
\hline
\end{tabular}

( ${ }^{1}$ Hybrids are in parentheses) 
